\title{
Activity of Antioxidant Enzymes in Soybean Genotypes under Drought Stress
}

\author{
Tejas Kanase $^{1 *}$, Arti Guhey ${ }^{1}$ and Dhanashri Gawas ${ }^{2}$ \\ ${ }^{I}$ Department of Plant Physiology, IGKV, Raipur, Chhattisgarh, India \\ ${ }^{2}$ Department of Plant Physiology, Dr. BSKKV, Dapoli, Maharashtra, India \\ *Corresponding author
}

K e y w o r d s
drought, antioxidant
enzymes,
superoxide
dismutase,
ascorbate
peroxidase,
catalase.

\section{A B S T R A C T}

We compared the enzymatic antioxidative defence mechanisms of some regional soybean genotypes cultivated mainly in the regions of Maharashtra and Chhattisgarh. The variability in the activities of antioxidant enzymes superoxide dismutase (SOD), ascorbate peroxidase (APX), catalase (CAT), and peroxidase (POD) and their changes under drought stress were investigated. The higher activity levels of antioxidant enzymes may contribute to better stress tolerance by increasing protection capacity against oxidative damage. Genotype NRC 37 and KDS 344 possessed higher SOD and APX activity which catalyzes superoxide free radical dismutation into $\mathrm{H}_{2} \mathrm{O}_{2}$ and $\mathrm{O}_{2}$ and defense against free radicals of oxygen under water stress. The maximum increase in peroxidase and catalase activity was recorded in leaves of NRC 37 and JS 335 help in biosynthesis of lignin which has a role in the defense against water stress by consuming $\mathrm{H}_{2} \mathrm{O}_{2}$. The antioxidant enzyme activities are used as indications of water stress in soybean plants and screening of drought resistant genotype.

\section{Introduction}

Soybean is the world's leading economic oilseed crop and the most widely grown oilseed worldwide, having reached a global production of 346.91 million metric ton in 2017-18 crop season. In India this crop is cultivated in 101.561 Lakh ha area with the production of 83.504 Lakh metric ton soybean. Chhattisgarh contributes nearly 1.32 Lakh ha area areas and 0.863 Lakh metric tons. However, the productivity of the crop in India is substantially low as compared to the advanced countries (SOPA 2017-18). The low productivity of soybean in India can be attributed to a range of abiotic and biotic stresses that affect crop growth and development. In particular, drought is a major 
constraint in a vast rainfed area sown to soybean. It is predicted that water deficit will continue to be a major abiotic factor affecting global crop yields (Sharma and Lavanya 2002). One-third of the world's population resides in water-stressed regions, with elevated $\mathrm{CO}_{2}$ levels in the atmosphere and climatic changes predicted in the future, drought could become more frequent and severe.

Growth and productivity of plants depend on environmental conditions. Water deficit is a major limiting factor of crop production under continental climates and there is a continuous demand for genetically new drought-resistant crops. One of the possibilities to improve drought resistance of cultivated crops is to find ancient regional subspecies or local races which are well adapted to local environmental conditions.

Drought is one type of oxidative stress that, at the cellular level, enhances the generation of active oxygen species (AOS), such as superoxide radicals $\left(\mathrm{O}^{-}{ }^{-}\right)$, hydrogen peroxide $\left(\mathrm{H}_{2} \mathrm{O}_{2}\right)$ and hydroxyl radicals $\left(\mathrm{OH}^{*}\right)$. Plants have developed different enzymatic and nonenzymatic scavenging mechanisms to control the level of AOS. The AOS can rapidly attack all types of biomolecules to cause membrane deterioration, lipid peroxidation and DNA mutation, leading to metabolic and structural dysfunctions and cell death (Halliwell and Gutteridge, 1989). In order to decrease these biological damages for survival, all organisms have evolved a well-integrated antioxidant system, including enzymatic and no enzymatic components. Due to this large number of processes that produce ROS, plants have evolved a series of detoxification reactions, which are located in distinct cell organelles. $\mathrm{H}_{2} \mathrm{O}_{2}$ formed during photorespiration by the conversion of glycolate into glyoxylate can be decomposed into $\mathrm{H}_{2} \mathrm{O}$ and $\mathrm{O}_{2}$ within the peroxisome, by catalase (CAT), which does not require an additional substrate (Scandalios, 1994). The scavenging of $\mathrm{H} 2 \mathrm{O} 2$ in other cell compartments depends on distinct peroxidases that use a reduced substrate for activity.

The level of antioxidants and the activities of antioxidant enzymes such as $\mathrm{H}_{2} \mathrm{O}_{2}$ related SOD, APX, CAT, and peroxidase POD are generally increased in plants under stress conditions and in several cases their activities correlate well with enhanced tolerance (Foyer et al., 1997). Superoxide radicals can be converted to hydrogen peroxide enzymatically by superoxide dismutases (SOD) has been extensively studied (Bowler et al., 1992). Three classes of SOD have been observed in plants, cytosolic and chloroplastic $\mathrm{Cu}$ Zn/SODs, a chloroplastic Fe/SOD and a mitochondrial $\mathrm{Mn} / \mathrm{SOD}$, of which the former two have been shown to be regulated by oxidative stress (Azevedo et al., 1998). Ascorbate peroxidases use ascorbate as a reducing substrate and have been shown to be localized in several cell compartments such as chloroplasts, the cytosol and microbodies (Corpas et al., 2001).

Recent reports on the responses of plant antioxidant enzymes to stress, have indicated several distinct patterns, which varied according to the species and tissue analysed (Ferreira et al., 2002). The aim of this study was to investigate the changes in activities of the antioxidant enzymes SOD, APX, POD, and CAT in the leaves of six soybean genotypes in response to drought stress.

\section{Materials and Methods}

\section{Plant material and soil}

Six genotypes of soybean including locally adapted varieties KDS 344, JS 335, MACS 1188, NRC 37, JS 9752, and CG soya were chosen for this experiment. Seed where sown by the hand using 3 hole plastic disc in all 
treatments. Three bold seeds were sown in 12 " diameter pots filled with $14 \mathrm{~kg}$ of clay loam soil and grown initially in under natural conditions outside the green house. Physicochemical properties of the soil used for experiments were as follows, $\mathrm{pH} \mathrm{8.4,} \mathrm{EC} 0.24$ $\mathrm{dSm}^{-1}$, organic carbon $6.3 \mathrm{~g} \mathrm{~kg}^{-1}, 170 \mathrm{~kg}$ nitrogen, $17 \mathrm{~kg}$ phosphorous and $140 \mathrm{~kg}$ potash ha-1.

\section{Experimental design and statistical analysis}

The experiment consisted of a randomized complete block design with two treatments: watered and water stress conditions. Eight replicates of each genotype treatment were done totalling 96 pots so that half of them were cultivated under watered conditions throughout the entire experiment, while the other half was water stress (drought-stressed). Drought stress was carried out by suspending watering of the $30 \mathrm{DAS}$ and watered pots were used as control. At this age the plant were at the vegetative stages. Watering ensured approximately $40 \%$ water content of the soil mixture, which decreased to $22 \%$. The analysis was performed in eight replicates on three plants of each soybean genotype.

Analysis of observations were taken on different variables was carried out to know the degree of variation among all the treatments. The data was statistically analyzed through completely randomized block design. The result obtained through analysis of variance.

\section{Activity measurements of antioxidant enzymes}

\section{Enzyme extraction}

Enzyme extract for superoxide dismutase, ascorbate peroxidase, catalase, and peroxidase was prepared by one gram of fresh leaf sample from watered and water stress plants were grinding in liquid nitrogen in mortar to prevent proteolytic activity followed by grinding in $4 \mathrm{ml}$ extraction buffer $(50 \mathrm{mM}$ phosphate buffer $\mathrm{pH} 7.0$, containing $1 \mathrm{mM}$ EDTA, $1 \mathrm{mM}$ phenylmethylsulfonyl fluoride and $1 \%$ polyvinylpolypirrolidone). The homogenate was centrifuged for $25 \mathrm{~min}$ at 15 $000 \times \mathrm{g}$ and $4^{\circ} \mathrm{C}$. The supernatant was used for enzyme activity assays.

SOD activity was determined spectrophotometrically by measuring the ability of the enzyme to inhibit the photochemical reduction of nitro blue tetrazolium (NBT) in the presence of riboflavin in light (Dhindsa et al., 1981). One unit (U) of SOD was the amount that causes a $50 \%$ inhibition of NBT reduction in light. The enzyme activity was expressed in terms of specific activity (U/mg protein). APX activity was measured in a $1-\mathrm{mL}$ reaction volume containing $50 \mathrm{mM}$ potassium phosphate buffer ( $\mathrm{pH} 7.0), 0.1 \mathrm{mM}$ hydrogen peroxide and $0.5 \mathrm{mM}$ ascorbate. Adding the $\mathrm{H} 2 \mathrm{O} 2$ started the reaction and the decrease in absorbance at $290 \mathrm{~nm}$ was recorded for $1 \mathrm{~min}$ to determine the oxidation rate of ascorbate (Nakano and Asada 1981). CAT activity was determined by the decomposition of $\mathrm{H}_{2} \mathrm{O}_{2}$ which, in turn, was measured by the decrease in absorbance at $240 \mathrm{~nm}$ (Aebi, 1984). One U equals the amount of $\mathrm{H}_{2} \mathrm{O}_{2}$ (in $\mu \mathrm{mol}$ ) decomposed in $1 \mathrm{~min}$. POD activity was determined by monitoring the increase in absorbance at $470 \mathrm{~nm}$ during the oxidation of guaiacol (Putter, 1974). The amount of enzyme producing $1 \mu \mathrm{mol} / \mathrm{min}$ of oxidized guaiacol was defined as $1 \mathrm{U}$. The protein contents of the extracts were determined by the method of Bradford (1976).

\section{Results and Discussion}

\section{Effect of drought on superoxide dismutase activity}

Water stress or severe water limitation is causes drastic changes in ion and water 
homeostasis which results in oxidative stress through accumulation of reactive oxygen species such as superoxide $\left(\mathrm{O}_{2}^{-}\right)$, hydroxyl radicals $\left(\mathrm{OH}^{-}\right)$and hydrogen peroxide $\left(\mathrm{H}_{2} \mathrm{O}_{2}\right)$ are produced in soybean plants naturally during cell metabolism in processes such as photosynthesis, photorespiration and fatty acid oxidation. The superoxide dismutase (SOD) is a potent antioxidant because it can catalyses superoxide free radical dismutation into $\mathrm{H}_{2} \mathrm{O}_{2}$ and $\mathrm{O}_{2}$ and be recognized as early defence against free radicals of oxygen (Liu and Huang 2000).

The watered treatment genotype NRC 37 (76.58) recorded the maximum SOD activity (Table 1) though did not vary significantly with JS 335 (70.77). Though KDS 344 (62.06) lagged behind the former but was at par with the JS 9752 (60.00) and MACS 1188 (59.27). The significant minimum SOD activity (53.86) value was noted in CG Soya. Water stress treatment genotype NRC 37 (101.28) possessed higher SOD activity and at par with KDS 344 (98.67), JS 335 (98.65) and MACS 1188 (90.06) while, proved significant superiority over rest of the genotypes. CG Soya (84.59) recorded lowest SOD activity.

The maximum per cent increase in superoxide dismutase activity under both treatments was recorded in leaves of KDS 344 (58.99). The minimum per cent increase in superoxide dismutase activity was recorded in leaves of NRC 37 (32.25). Superoxide dismutase (SOD) activities increased in response to water stress (Kukreja et al., 2005). The maximum activity of SOD $(1127 \mathrm{u} / \mathrm{g}$ protein) found in drought stress condition and the minimum activity of the enzyme found in normal irrigation (709 u/g protein) (Mohammadi et al., 2011). The SOD activities of seedling leaves were increasingly expressed in Xinong928 in one to two days of drought stress (Mingyang et al., 2015).

\section{Effect of drought on Ascorbate peroxidase activity}

Soybean plants are exposed to water stress conditions the formation of ROS (reactive oxygen species) increases and can make critical harm the cells. The ascorbate peroxidase (APX) enzymes play a major key factor catalyzing the change of $\mathrm{H}_{2} \mathrm{O}_{2}$ into $\mathrm{H}_{2} \mathrm{O}$ utilizing ascorbate as a particular electron benefactor Ascorbate as a lessening substrate is available in unmistakable subcellular compartments, such as chloroplasts and cytosol. The APX reactions are legitimately associated with the insurance of plant cells against water stress conditions.

From the Table 1, it was revealed that watered treatment genotype NRC 37 (16.75) recorded the maximum ascorbate peroxidase activity but was at par with JS 335 (16.23), KDS 344 (14.33) and JS 9752 (13.77). Water stress treatment genotypes NRC 37 (26.31), KDS 344 (25.34) and JS 335 (25.06) recorded the higher ascorbate peroxidase activity though they differed significantly among them. Though JS 9752 (22.71) had the lower values as compared to the former but was at par with MACS 1188 (22.48). CG Soya (22.93) registered the minimum ascorbate peroxidase activity in both treatments.

The maximum per cent increase in ascorbate peroxidase activity under both treatments was recorded in leaves of KDS 344 (76.81). The minimum per cent increase in ascorbate peroxidase activity was recorded in leaves of CG Soya (22.93). The APX activity was enhanced in the leaves of drought tolerant cultivar of soybean plants under water stress. Otherwise salt treatment alone did not change the APX activity in the leaves of this plant (Yu and Liu 2003). Increase in APX amount and activity with increasing drought in soybeans. 
Table.1 SOD and APX enzymes activities of genotypes under the watered and water stress treatments

\begin{tabular}{|c|c|c|c|c|c|c|}
\hline \multirow[t]{2}{*}{ Genotypes } & \multicolumn{3}{|c|}{ SOD (units $\mathrm{mg}^{-1}$ protein) } & \multicolumn{3}{|c|}{ APX (units mg $^{-1}$ protein) } \\
\hline & Watered & $\begin{array}{l}\text { Water } \\
\text { stress }\end{array}$ & $\begin{array}{l}\% \\
\text { increase }\end{array}$ & Watered & $\begin{array}{l}\text { Water } \\
\text { stress }\end{array}$ & $\begin{array}{l}\% \\
\text { increase }\end{array}$ \\
\hline CG Soya & 53.86 & 84.59 & 57.04 & 7.53 & 9.26 & 22.93 \\
\hline JS 335 & 70.77 & 98.65 & 39.38 & 16.23 & 25.06 & 54.44 \\
\hline JS 9752 & 60.00 & 87.71 & 46.19 & 13.77 & 22.71 & 64.93 \\
\hline KDS 344 & 62.06 & 98.67 & 58.99 & 14.33 & 25.34 & 76.81 \\
\hline MACS 1188 & 59.27 & 90.06 & 51.96 & 12.77 & 22.48 & 75.97 \\
\hline NRC 37 & 76.58 & 101.28 & 32.25 & 16.75 & 26.31 & 57.10 \\
\hline Total & 382.55 & 560.96 & & 81.38 & 131.16 & \\
\hline SEm \pm & 4.260 & 4.062 & & 1.097 & 0.886 & \\
\hline CD at $5 \%$ & 12.407 & 11.831 & & 3.195 & 2.581 & \\
\hline
\end{tabular}

Table.2 POD and CAT enzymes activities of genotypes under the watered and water stress treatments

\begin{tabular}{|c|c|c|c|c|c|c|}
\hline \multirow[t]{2}{*}{ Genotypes } & \multicolumn{3}{|c|}{ POD (units ${ }^{-1} \mathrm{~min}^{-1} \mathrm{~g}^{-1}$ ) } & \multicolumn{3}{|c|}{ CAT (units ${ }^{-1} \min ^{-1} \mathrm{~g}^{-1}$ ) } \\
\hline & Watered & $\begin{array}{l}\text { Water } \\
\text { stress }\end{array}$ & $\begin{array}{l}\% \\
\text { increase }\end{array}$ & Watered & $\begin{array}{l}\text { Water } \\
\text { stress }\end{array}$ & $\begin{array}{l}\% \\
\text { increase }\end{array}$ \\
\hline CG Soya & 6.70 & 8.09 & 20.81 & 13.78 & 16.09 & 16.78 \\
\hline JS 335 & 10.94 & 19.48 & 78.06 & 18.06 & 26.15 & 44.77 \\
\hline JS 9752 & 5.44 & 9.17 & 68.71 & 15.44 & 22.48 & 45.64 \\
\hline KDS 344 & 11.16 & 17.06 & 52.86 & 19.16 & 25.84 & 34.82 \\
\hline MACS 1188 & 9.06 & 15.31 & 68.99 & 17.11 & 24.23 & 41.64 \\
\hline NRC 37 & 14.25 & 19.71 & 38.30 & 22.75 & 29.64 & 30.30 \\
\hline Total & $\mathbf{5 7 . 5 5}$ & 88.83 & & 106.30 & 144.43 & \\
\hline SEm \pm & 1.217 & 1.691 & & 1.930 & 1.343 & \\
\hline CD at $5 \%$ & 3.544 & 4.926 & & 5.621 & 3.911 & \\
\hline
\end{tabular}

The APX is one of the enzymes responsible for scavenging $\mathrm{H}_{2} \mathrm{O}_{2}$ which may be produced during water deficits and significant increases in activity in the tolerant cultivars (Kausar et al., 2012).

\section{Effect of drought on peroxidase activity}

Water stressed soybean leaves strongly enhanced the activities of peroxidase, which could be considered as a response to stressinduced oxidative damage and enzymatic removal of $\mathrm{H}_{2} \mathrm{O}_{2}$ by peroxidase. Watered treatment genotypes NRC 37 (14.25), KDS 344 (11.16) and JS 335 (10.94) recorded the higher peroxidase activity (Table 2) though they differed significantly among them.

Though MACS 1188 (9.06) lagged behind the former but was at par with the CG Soya (6.70). JS 9752 (5.44) registered the minimum peroxidase activity. Water stress treatment genotype NRC 37 (19.71) noted the higher peroxidase activity though did not vary significantly with JS 335 (19.48), KDS 344 (17.06) and MACS 1188 (15.31). CG Soya 
(8.09) recorded the minimum peroxidase activity. The maximum per cent increase in peroxidase activity under both treatments was recorded in leaves of JS 335 (78.06). The minimum per cent increase in peroxidase activity was recorded in leaves of CG Soya (20.81). Significantly increase peroxidase activity in soybean genotype NRC 37 which protects the cellular damage by converts the toxic $\mathrm{O}_{2}^{-}$and $\mathrm{H}_{2} \mathrm{O}_{2}$ to water and molecular oxygen $\left(\mathrm{O}_{2}\right)$ under water stress. Higher peroxidase enzyme activity was obtained under drought stress and can be attributed to the plant defence mechanisms against free radical formation resulting from water deficit (Ruppenthal et al., 2016). Peroxidase enzyme activity increased under drought stress and used in the selection of soybean genotypes with greater tolerance to drought (Zoz et al., 2013).

\section{Effect of drought on Catalase activity}

Catalase plays a crucial role in determining the tolerance of a plant under water stress. Increase in the level of antioxidant enzyme catalase (CAT) with increase in water stress intensity. Watered treatment genotype NRC 37 (22.75) possessed higher catalase activity (Table 2) and at par with KDS 344 (19.16) and JS 335 (18.06) while, proved significant superiority over rest of the genotypes. Water stress treatment genotypes NRC 37 (29.64), JS 335 (26.15) and KDS 344 (25.84) recorded the higher catalase activity though they differed significantly among them. Though MACS 1188 (24.23) had the lower values as compared to the former but was at par with JS 9752 (22.48). CG Soya registered the minimum catalase activity in both treatments.

The maximum per cent increase in catalase activity under watered and water stress treatment was recorded in leaves of JS 9752 (45.64). The minimum per cent increase in catalase activity was recorded in leaves of CG
Soya (16.78). The water stress-induced increases in catalase antioxidant enzyme activities were observed in the NRC 37 soybean genotype. The drought stress treatment increase in activity of antioxidant enzymes like catalase (CAT) that allow this species to present a high degree of drought tolerance characters (Adriano et al., 2015). The increase in catalase (CAT) activity detected for Detam-1 and Detam-2 soybean genotypes (Damanik et al., 2016).

The present study clearly showed that amongst six genotypes of soybean NRC 37, JS 335 and KDS 344 was significantly exhibited the higher activity of superoxide dismutase, ascorbate peroxidase, catalase and peroxidase those play a critical role in detoxifying reactive oxygen species (ROS) induced by water stress. Changes in the activities of antioxidant enzymes during drought stress indicated that the antioxidant system plays a fundamental role in the identifying the drought resistant soybean genotypes.

\section{References}

Adriano, S., Antonio, S., Maria, N. and Antonella, V. 2015. Ascorbate Peroxidase and Catalase Activities and Their Genetic Regulation in Plants Subjected to Drought and Salinity Stresses. Int. Journal Mol. Sci. 16. 13561-13578;

Aebi, H. 1984. Catalase in vitro. Methods in Enzymology. 105: 121-126.

Anonymous, 2017-18. Soybean Processors Association of India. www.sopa.org/statistics.

Azevedo, R.A., Alas, R.M., Smith, R.J. and Lea, P.J. 1998. Response of antioxidant enzymes to transfer from elevated carbon dioxide to air and ozone fumigation, in the leaves and roots of wild-type and a catalasedeficient mutant of barley. Physiol. 
Plant. 104: 280-292.

Bowler, C., Montagu, M. and Inze, D. 1992. Superoxide dismutase and stress tolerance. Annual Review of Plant Physiology and Plant Molecular Biology. 43: 83-116.

Bradford, M.M., 1976. A rapid and sensitive method for the quantitation of microgram quantities of protein utilizing the principle of protein-dye binding. Anal. Biochem. 72: 248-254.

Corpas, F.J., Barroso, J.B. and Rio. L.A. 2001. Peroxisomes as a source of reactive oxygen species and nitric oxide signal molecules in plant cells. Trends Plant Sci. 6: 145-150.

Damanik, R.I., Marbun, P. and Sihombing, L. 2016. Antioxidant activity of seedling growth in selected soybean genotypes (Glycine max (L.) Merrill) responses of submergence. Earth and Environmental Science. 41(1): 012003.

Dhindsa, R.S., Plumb,D.P. and Thorpe, T.A. 1981. Leaf senescence: correlated with increased levels of membrane permeability and lipid peroxidation, and decreased levels of superoxide dismutase and catalase. J. Exp. Bot. 32: 93-101.

Ferreira, R.R., Francisco, F.R., Pierre, V.A., Lea, P.J. and Antunes, A.R. 2002. Changes in antioxidant enzyme activities in soybean under cadmium stress. Journal of Plant Nutrition. 25: 327-342.

Foyer, C.H., Lopez, D. H., Dat, J.F. and Scott, I.M. 1997. Hydrogen peroxide- and glutathione-associated mechanisms of acclimatory stress tolerance and signalling. Physiol. Plant. 100: 241254.

Halliwell, B., and Gutteridge, J.M.C. 1989. Free radicals in biology and medicine, 2nd edn. Oxford, UK: Clarendon Press.

Kausar, R., Hossain, Z., Makino, T. and
Komatsu, S. 2012. Characterization of ascorbate peroxidase in soybean under flooding and drought stresses. Mol Biol Rep. 39(12): 10573-10579.

Kukreja, S., Nandval, A., Kumar, N., Sharma, K, Unvi, V. and Sharma, P.K. 2005. Plant water status, $\mathrm{H} 2 \mathrm{O} 2$ evolution and membrane integrity of Cicer arietinum roots as affected by salinity. Plant Biology. 49: 305-308.

Liu, X. and Huang, B. 2000. Heat stress injury in relation to membrane lipid peroxidation in creeping bentgrass. Crop Science. 40: 503-510.

Mingyang, W., Lirong, C., Fenling, L., Min, Z., Lunshan, S. Y. and Xiping Deng. 2015. Effects of drought stress on antioxidant enzymes inSeedlings of different wheat genotypes. Pak. J. Bot. 47(1): 49-56.

Mohammadi, A., Davood, H., Mahyar, R. and Saeed, M. 2011. Effect of drought stress on antioxidant enzymes activity of some chickpea cultivars. AmericanEurasian J. Agric. and Environ. Sci. 11(6): 782-785.

Nakano, Y. and Asada, K. 1981. Hydrogen peroxide is scavenged by ascorbatespecific peroxidase in spinach chloroplasts. Plant and Cell Physiology. 22: 867-880.

Prasad., T.K., Anderson, M.D., Martin, B.A. and Stewart, C.R. 1994. Evidence for chilling-induced oxidative stress in maize seedlings and a regulatory role for hydrogen peroxide. Plant Cell, 6: 65-74.

Putter, J. 1974. Method of Enzymatic method analysis 2,(Ed.): Bergmeyer. Academic Press, New York. 685.

Ruppenthal, V., Tiago, Z., Faabio, S., Maria, C.L. and Deise, D.C. 2016. Silicon does not alleviate the adverse effects of drought stress in soybean plants. Semina: Ciencias Agrarias Londrina. 37(6): 3941-3954. 
Scandalios, J.G., 1993. Oxygen stress and superoxide dismutases. Plant Physiol., 101: 7-12.

Sharma, K.K. and Lavanya, M. 2002. Recent developments in transgenics for abiotic stress in legumes of the semi-arid tropics. JIRCAS Working Report. 6173.

Yu, B.J. and Liu, Y.L. 2003. Effects of salt stress on the metabolism of active oxygen in seedlings of annual halophyte Glycine soja. Acta Bot Boreal Occident.Sin., 23: 18-22.

Zoz, T., Steiner, F., Guimaraes, V. F., Castagnara, D.D., Meinerz, C.C. and Fey, R. 2013. Peroxidase activity as an indicator of water deficit tolerance in soybean cultivars. Bioscience Journal Uberlandia. 29(5): 1664-1671.

\section{How to cite this article:}

Tejas Kanase, Arti Guhey and Dhanashri Gawas 2019. Activity of Antioxidant Enzymes in Soybean Genotypes under Drought Stress. Int.J.Curr.Microbiol.App.Sci. 8(09): 2323-2330. doi: https://doi.org/10.20546/ijcmas.2019.809.267 